\title{
Islet amyloid polypeptide in diabetic and non-diabetic Pima Indians
}

\author{
A.Clark ${ }^{1}$, M.F.Saad ${ }^{2}$, T.Nezzer ${ }^{1}$, C. Uren ${ }^{1}$, W.C. Knowler ${ }^{2}$, P.H. Bennett ${ }^{2}$ and R.C. Turner ${ }^{1}$ \\ ${ }^{1}$ Diabetes Research Laboratories, Radcliffe Infirmary, Oxford, UK, and ${ }^{2}$ Diabetes and Arthritis Epidemiology Section, Phoenix \\ Epidemiology and Clinical Research Branch, National Institute of Diabetes and Digestive and Kidney Diseases, National Institutes of \\ Health, Phoenix, Arizona, USA
}

\begin{abstract}
Summary. Islet amyloid may have a pathological role in the development of Type 2 (non-insulin-dependent) diabetes mellitus. The prevalence of islet amyloid has been investigated on post-mortem pancreatic tissue from both diabetic and non-diabetic Pima Indian subjects who had previously been assessed by oral glucose tolerance tests. Islets were examined for amyloid deposits and for cellular immunoreactivity to pancreatic hormones and islet amyloid polypeptide, the constituent peptide of islet amyloid. Twenty of 26 diabetic subjects $(77 \%)$ had islet amyloid, compared with one of 14 non-diabetic subjects (7\%). Twelve of the diabetic subjects $(46 \%)$ had amyloid in more than $10 \%$ of their islets, whereas
\end{abstract}

only $4 \%$ of islets were affected in a single non-diabetic subject. Positive immunoreactivity for islet amyloid peptide was present in the islet amyloid and in islet cells in $54 \%$ of the diabetic and $50 \%$ of the non-diabetic subjects. Islet amyloid in diabetic Pima Indians may indicate a primary Beta-cell defect which interacts with insulin resistance to produce diabetes, or may develop as a result of Beta-cell dysfunction induced by insulin resistance and hyperglycaemia.

Key words: Pima Indians, diabetes mellitus, pancreatic islets, islet amyloid, islet amyloid polypeptide, insulin resistance, glucose tolerance.
The observation by Opie in 1901 of hyaline infiltration, later shown to be amyloid, in islets of a diabetic patient was the first indication that islet pathology may be associated with diabetes [1]. Islet amyloid has been found in up to $87 \%$ of European Type 2 (non-insulin-dependent) diabetic subjects [2-4] and in diabetic patients in India [5], Japan [6] and North America [7,8] but its relationship to the pathophysiology of the disease is unknown. Islet amyloid may have a primary role in the aetiology of Type 2 diabetes in man $[9,10]$ : islet deposits precede the onset of glucose intolerance in spontaneously diabetic monkeys [11] and accumulation of amyloid adjacent to the Beta-cells may have a pathogenic effect on hormone secretion. Alternatively, amyloid formation may be a secondary phenomenon resulting from aberrant peptide processing or abnormal regulation of insulin secretion since amyloid formed from the same peptide is found in some insulinomas [12].

The major protein constituent of pancreatic amyloid fibrils is a 37 amino acid peptide, islet amyloid polypeptide (IAPP) [13,14], (also known as diabetes associated peptide [9], or "amylin" [15]. Islet amyloid is not found in Type 1 (insulin-dependent) diabetes nor in experimental models of diabetes in laboratory animals. However, cDNA analyses have shown species-specific variants of the peptide to be present in many animals including the mouse, dog and rat $[16,17]$ with amyloid being associated with diabetes only in the cat [18], monkey [11] and man [2-8].
Pima Indians, who live in Arizona, have a high prevalence of Type 2 diabetes [19], are commonly obese and hyperinsulinaemic and exhibit a familial aggregation of insulin resistance [20-22]. Increased insulin resistance is thought to be the initial metabolic defect leading to diabetes in this group [23-26] but pathological changes in the pancreas have not been reported. Clinical documentation of these subjects is extensive, including glucose tolerance tests and the presence of diabetes in relatives. They therefore form an ideal population to examine the relationship of amyloid formation to Type 2 diabetes. Quantitative estimates of islet amyloidosis and of intracellular immunoreactivity for IAPP have been determined in histological sections of available post-mortem pancreatic tissue from diabetic and non-diabetic individuals and the results related to the clinical history of the subjects.

\section{Subjects and methods}

\section{Clinical data}

This study included 26 diabetic and 14 non-diabetic subjects on whom autopsy had been performed (Table 1). The clinical data were obtained from notes made on the last visit of the patients to the National Institute of Health Clinic and from hospital records and autopsy reports. Visits to the Clinic are a part of a longitudinal epidemio- 


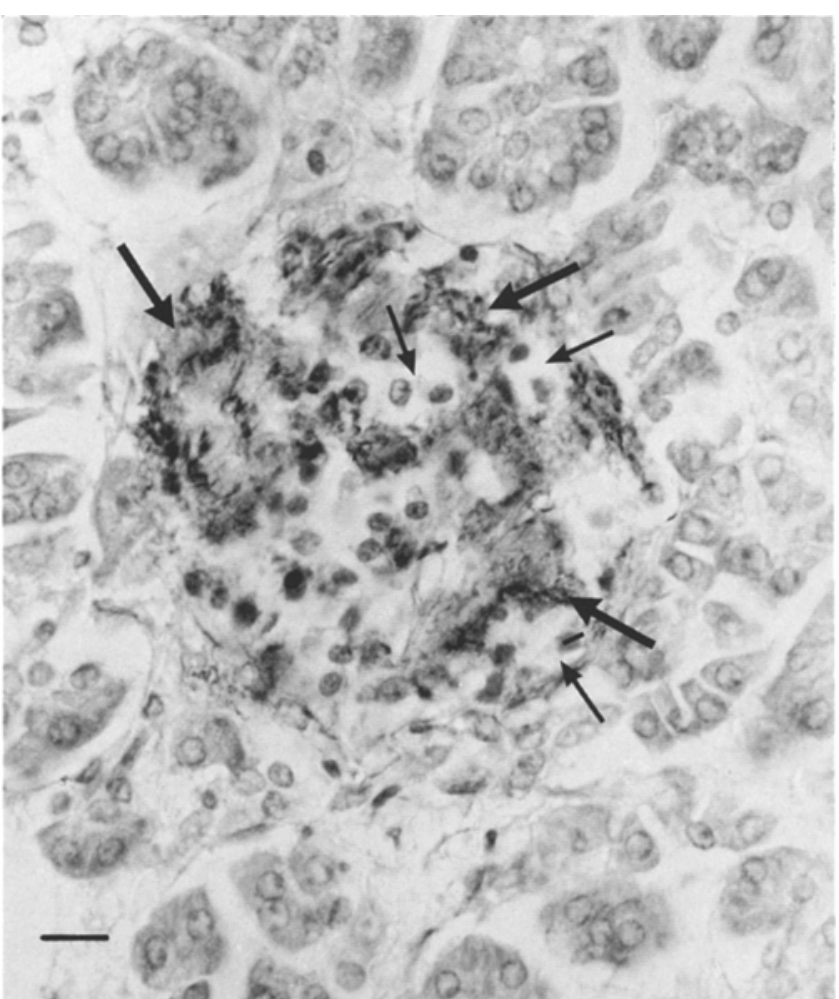

Fig.1. Islet amyloid in an islet from a diabetic Pima Indian subject stained with immunoperoxidase for islet amyloid polypeptide. Amyloid deposits (large arrows) are present throughout the islet adjacent to the endocrine cells (small arrows). Scale bar $=10 \mu \mathrm{m}$

logical study of diabetes among the Pima Indians in which every subject over the age of 5 years is examined approximately every two years. Each examination includes a medical history, a physical examination and an oral glucose tolerance test with $75 \mathrm{~g}$ glucose-equivalent carbohydrate load.

Glucose tolerance was categorised into normal, impaired or diabetic according to the World Health Organisation criteria [27]. Diabetes was determined in first-degree relatives (parents, siblings and offspring) who were examined in the research clinic by the same methods. Relatives who had not developed diabetes and were $\geq 45$ years old were considered free of the disease whereas those who had not developed diabetes and were $<45$ years old were considered to be indeterminate.

\section{Immunohistochemistry and morphometry}

A sample of pancreatic tissue from the body region of the pancreas was obtained at autopsy within $24 \mathrm{~h}$ of death. The tissues were fixed in $10 \%$ formaldehyde in $0.9 \%$ sodium chloride or in Bouin's solution and embedded in wax. Serial sections, $5 \mu \mathrm{m}$ thick were cut from each tissue block and stained for islet peptides using the indirect immunoperoxidase method [28] and primary antibodies to insulin (diluted 1/1000), glucagon (diluted 1/2000; Dako Ltd, High Wycombe, UK) pancreatic polypeptide (diluted 1/1500; RIA, Washington, UK), somatostatin (diluted 1/2000; RIA, Washington, UK) and IAPP ${ }_{19-37}$ (diluted 1/1000). All sections were counterstained with haematoxylin. Two adjacent sections were stained for (a) IAPP or (b) insulin combined with Congo red to demonstrate islet amyloid. Only pancreatic specimens with good morphological preservation were studied and some specimens were omitted from both groups because of poor preservation. Specificity of the antibodies was demonstrated by lack of immunoreactivity following (a) omission of the primary anti- body and (b) preabsorption of the diluted primary antibody with the appropriate antigen.

The total number of islet transections in the tissue specimen was counted on the slide stained for insulin. Quantitation of the islet sections containing amyloid was made on the adjacent histological section immunostained for IAPP. Assessment of the histological sections was made by two independent observers (TN and AC) who were unaware of the subjects' clinical data. The slides were examined on a projected image, magnified $\times 370$. A complete tissue section was examined in adjacent fields and measurements made of the total area of tissue examined (range $12-200 \mathrm{~mm}^{2}$, mean $\pm 1 \mathrm{SD}$, $97 \pm 39 \mathrm{~mm}^{2}$ ), the total number of islets and the number of islets containing amyloid as shown by extracellular deposits staining pink with Congo red and immunoreactive for IAPP.

\section{Results}

This study included 26 diabetic and 14 non-diabetic Pima Indians (12 with normal glucose tolerance and two with impaired glucose tolerance). The clinical and histological characteristics of each group are shown in Table 1 . Twenty of the 26 diabetic subjects ( $77 \%$ ) had islet amyloid identified by immunoreactivity for IAPP and positive staining with Congo red (Fig. 1). Up to $86 \%$ of the islets of diabetic subjects contained amyloid and in some cases amyloid occupied most of the islet sections. Tables 2 and 3 show detailed clinical characteristics of the subjects. Twelve diabetic subjects $(46 \%)$ had substantial amyloid infiltration (deposits present in at least $10 \%$ of islet sections) whereas only $4 \%$ of islets were affected in only one nondiabetic individual. There was no correlation between the number of islets with amyloid and the age, body mass index, the $2 \mathrm{~h}$ post-load plasma glucose concentration, duration of diabetes or the type of treatment. The prevalence of amyloid was higher in older subjects (Table 4). In the non-diabetic subjects, amyloid was not present in islets of the six obese subjects (body mass index $\geq 27 \mathrm{~kg} / \mathrm{m}^{2}$ ) nor in the two subjects with impaired glucose tolerance.

Immunoreactivity for the islet amyloid peptide was identified within the islet cells in $14(54 \%)$ of the 26 diabetic subjects including 10 of the 20 subjects who also

Table 1. Clinical and histological characteristics of the diabetic and non-diabetic subjects

\begin{tabular}{|c|c|c|}
\hline & $\begin{array}{l}\text { Diabetic } \\
(n=26)\end{array}$ & $\begin{array}{l}\text { Non-diabetic }{ }^{\mathrm{a}} \\
(n=14)\end{array}$ \\
\hline Age at death (years) ${ }^{b}$ & $66.5(41-89)$ & $62.0(27-87)$ \\
\hline $\operatorname{Sex}(M / F)$ & $13 / 13$ & $7 / 7$ \\
\hline Body mass index $\left(\mathrm{kg} / \mathrm{m}^{2}\right)^{\mathrm{b}}$ & $27.0(19-37)$ & $25(19-45)$ \\
\hline $\begin{array}{l}\text { Number (\%) of subjects } \\
\text { with amyloid deposition }\end{array}$ & $20(77 \%)$ & $1(7 \%)$ \\
\hline Number of islets examined ${ }^{b}$ & $127(36-494)$ & $113(71-537)$ \\
\hline $\begin{array}{l}\% \text { of islet sections with } \\
\text { amyloid deposition }^{\mathrm{b}}\end{array}$ & $7(0-86)$ & $0(0-4)$ \\
\hline $\begin{array}{l}\text { Number }(\%) \text { of subjects } \\
\text { with IAPP immunoreactive } \\
\text { islet cells }\end{array}$ & $14(54 \%)$ & $7(50 \%)$ \\
\hline
\end{tabular}


Table 2. Clinical details and quantitation of islet sections with amyloid in diabetic Pima Indians

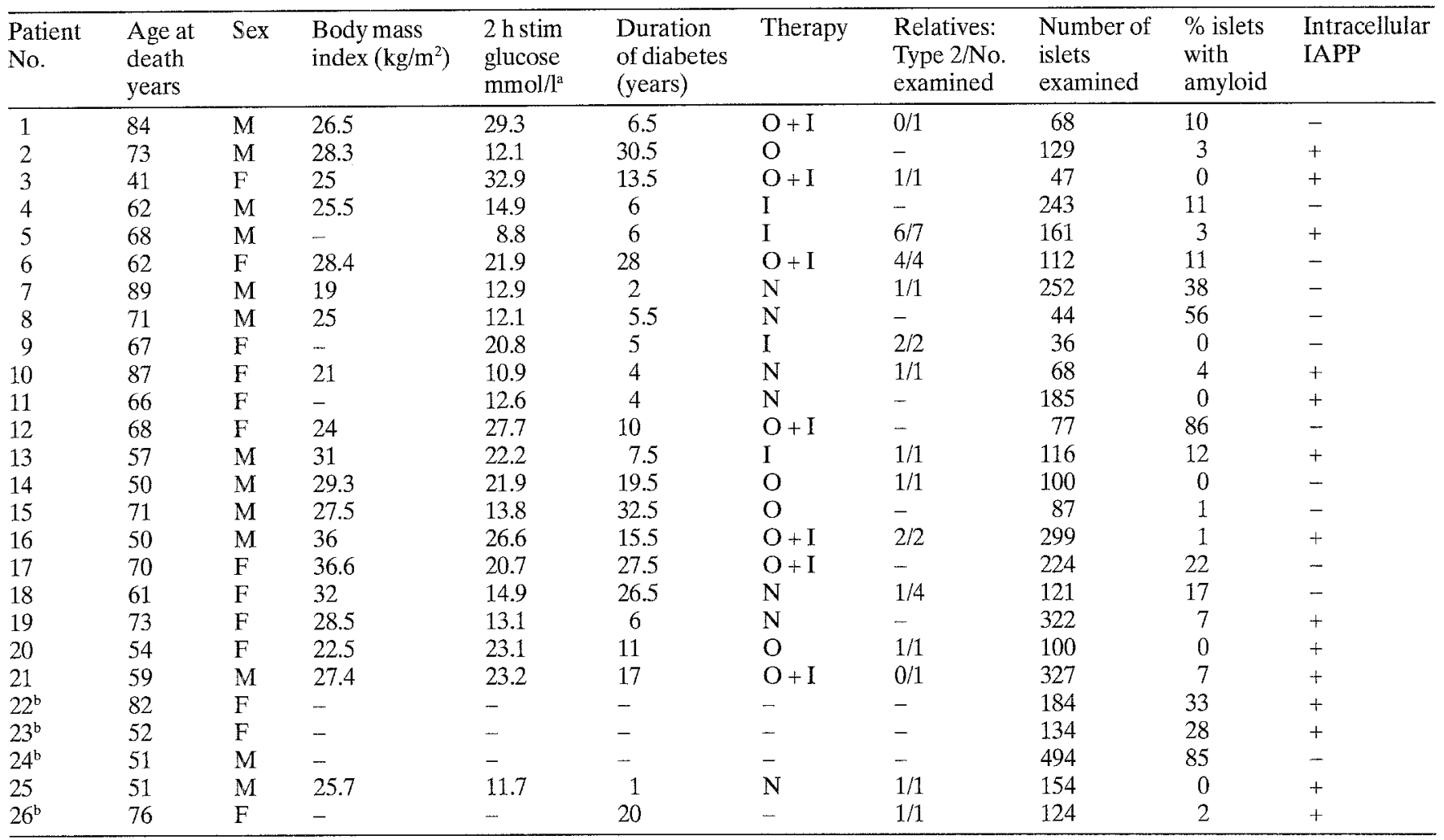

${ }^{a}$ Data collected at last biennial examination before death ( $0.5-13$ years, median 2 years).

b Subjects were not examined at the research clinic.

IAPP = islet amyloid polypeptide, $\mathrm{O}=$ oral hypoglycaemic agent, $\mathrm{I}=$ insulin, $\mathrm{N}=$ no drug treatment

Table 3. Clinical details and quantitation of islet sections with amyloid in non-diabetic Pima Indians

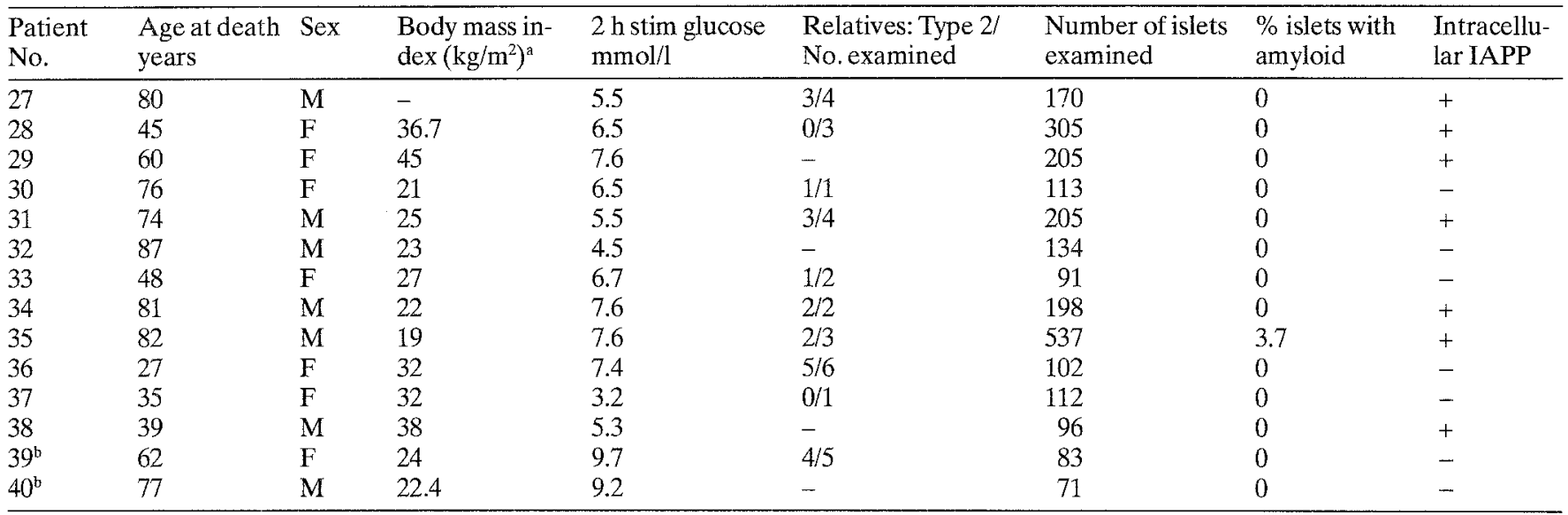

Data collected at last biennial examination before death ( $0.5-6$ years, median 2 years).

b Impaired glucose tolerance.

IAPP = islet amyloid polypeptide

had amyloid deposits and in 7 of 14 non-diabetic subjects $(50 \%)$. Positive immunoreactivity for insulin, glucagon and somatostatin was present in all islets and for pancreatic polypeptide in some islets, of both diabetic and nondiabetic subjects.

Ductular and exocrine fibrosis and deposition of fat were noted in the exocrine tissue in several subjects with no differences between the diabetic and non-diabetic groups. There was no evidence of lymphocytic infiltrates in islets of any of the 41 subjects.

\section{Discussion}

This is the first study to examine the prevalence of islet amyloid in post-mortem tissue from diabetic and nondiabetic subjects who had been characterised with a glucose tolerance test in life. In addition, Pima Indians represent a more homogeneous group than can be obtained from most routine hospital autopsies insofar as they appear to have exclusively Type 2 diabetes even when the disease presents at an early age $[29,30]$. Islet amyloid was 
Table 4. The relationship between islet amyloidosis and age, body mass index, 2-h post-load plasma glucose, duration of diabetes and type of treatment

\begin{tabular}{|c|c|c|}
\hline & $\begin{array}{l}\text { No }(\%) \text { of sub- } \\
\text { jects with islet } \\
\text { amyloidosis }\end{array}$ & $\begin{array}{l}\% \text { of islet } \\
\text { with amy- } \\
\text { loidosis }^{\mathrm{a}}\end{array}$ \\
\hline $\begin{array}{l}\text { Age at death } \\
<61 \text { years }(n=9) \\
61-70 \text { years }(n=8) \\
\geq 71 \text { years }(n=9)\end{array}$ & $\begin{array}{l}5(56 \%) \\
6(75 \%) \\
9(100 \%)\end{array}$ & $\begin{aligned} 1 & (0-85) \\
11 & (0-86) \\
7 & (1-57)\end{aligned}$ \\
\hline $\begin{array}{l}\text { Body mass index } \\
<26 \mathrm{~kg} / \mathrm{m}^{2}(n=6) \\
26-28 \mathrm{~kg} / \mathrm{m}^{2}(n=7) \\
\geq 29 \mathrm{~kg} / \mathrm{m}^{2}(n=6)\end{array}$ & $\begin{array}{l}4(67 \%) \\
6(86 \%) \\
5(83 \%)\end{array}$ & $\begin{aligned} 21 & (0-86) \\
7 & (0-11) \\
10 & (0-22)\end{aligned}$ \\
\hline $\begin{array}{l}\text { 2- } h \text { post-load plasma glucose } \\
<13.8 \mathrm{mmol} / 1(n=7) \\
13.8-22.0 \mathrm{mmol} / \mathrm{l}(n=7) \\
>22.2 \mathrm{mmol} / \mathrm{l}(n=7)\end{array}$ & $\begin{array}{l}6(75 \%) \\
5(71 \%) \\
5(71 \%)\end{array}$ & $\begin{array}{r}4(0-57) \\
11(0-22) \\
7(0-86)\end{array}$ \\
\hline $\begin{array}{l}\text { Duration of diabetes } \\
<7 \text { years }(n=8) \\
7-19 \text { years }(n=7) \\
>20 \text { years }(n=7)\end{array}$ & $\begin{array}{l}6(67 \%) \\
5(71 \%) \\
6(86 \%)\end{array}$ & $\begin{array}{ll}4 & (0-57) \\
7 & (0-86) \\
3 & (0-22)\end{array}$ \\
\hline $\begin{array}{l}\text { Type of treatment } \\
\text { No drug }(n=6) \\
\text { Oral hypoglycaemic agents }(n=4) \\
\text { Insulin }(n=5) \\
\text { Oral hypoglycaemic agents and } \\
\text { insulin }(n=6)\end{array}$ & $\begin{array}{l}5(83 \%) \\
2(50 \%) \\
4(80 \%)\end{array}$ & $\begin{aligned} 12 & (0-57) \\
1 & (0-3) \\
3 & (0-12)\end{aligned}$ \\
\hline
\end{tabular}

${ }^{a}$ Median is given with range in parenthesis

found in $77 \%$ of the diabetic but in only $7 \%$ of the nondiabetic Pima Indians of comparable age, sex and weight. Thus, the prevalence of islet amyloid is high in Type 2 diabetes in Pima Indians and comparable to that in other ethnic groups $[2,3,5,8]$. Early studies of the prevalence of islet amyloid in autopsy material from non-diabetic and diabetic subjects have suffered from inadequate separation of Type 1 and Type 2 diabetes and from lack of accurate identification of diabetes by glucose tolerance tests in life [5-7]. The absence of islet amyloid in the two subjects with glucose intolerance suggests that, unlike spontaneous diabetes in monkeys [9], islet amyloid formation may not precede the onset of diabetes in man. However, it would require examination of more than one tissue specimen from the corpus region of the pancreas, where amyloid is found more commonly [2,31], to exclude the presence of amyloid in a subject [8].

Immunoreactivity for IAPP has been found in secretory granules and lysosomes of Beta cells in nondiabetic subjects and in secretory granules of cats $[32,33]$. A deficiency of IAPP in islet cells of diabetic subjects has been reported [4]. However, immunoreactivity for IAPP was detected in islet cells of diabetic and non-diabetic Pima Indians with similar frequencies. The inability to demonstrate immunoreactivity for IAPP in islet cells of some diabetic and non-diabetic subjects may result from imperfect tissue fixation and preservation: intracellular immunoreactive sites are more sensitive to autolysis than the extracellular amyloid deposits.

The mechanism of amyloid formation from IAPP is unknown. Formation of a genetically determined abnormal peptide in diabetes is unlikely since the amino acid se- quence of IAPP predicted from cDNA analysis has an identical sequence to that of the peptide extracted from amyloid in diabetic subjects $[34,35]$. Insulin and IAPP may be co-secreted from Beta cells [36]: rat-IAPP is released with insulin from isolated rat islets in response to glucose [37]. Hence, hypersecretion of insulin (and IAPP) in the course of diabetes could lead to amyloid formation. This may also be the mechanism of amyloid deposition in insulinomas which are characterised by excessive insulin and proinsulin production $[12,38]$. High proinsulin levels have been detected in a patient with Type 2 diabetes who was known to have islet amyloid [39]. However, amyloid was not found in non-diabetic Pima Indians with large body mass index or impaired glucose tolerance which are clinical conditions associated with hyperinsulinaemia.

There could be several pathogenic mechanisms leading to Type 2 diabetes in Pima Indians, one of which is amyloid deposition; their glucose intolerance is characterised by insulin resistance whereas Beta cell dysfunction occurs later as diabetes develops [26]. Accumulation of amyloid between the islet cells and capillaries may directly affect Beta-cell function or disrupt the paracrine and neural control of endocrine secretion resulting in the disordered insulin production characteristic of Type 2 diabetes $[40,41]$. Alternatively islet amyloid could arise from abnormal function of the Beta cell induced by secondary hyperglycaemia, resulting in excessive formation and/or abnormal catabolism of the peptide.

Acknowledgements. We are grateful to the staff of the Pathology Departments at the Phoenix Indian Medical Centre and Veterans Administration Medical Centre, Phoenix, Arizona for performing the autopsies; to Dr. J. Rothbard for synthesis of IAPP and to Dr. C. Edwards and Ms B. Naylor for the production of the antisera to IAPP and insulin respectively (DRL, Oxford); and to Ms. P. Davis and Ms. C.K. Gishie for typing the manuscript. This work was supported in part by a grant from the British Diabetic Association.

\section{References}

1. Opie $\mathrm{E}$ (1901) The relation of diabetes mellitus to lesions of the pancreas. Hyaline degeneration of the islets of Langerhans. J Exp Med 5: 527-540

2. Clark A, Wells CA, Buley ID, Cruickshank JK, Vanhegan RI, Matthews DR, Cooper GJS, Holman RR, Turner RC (1988) Islet amyloid, increased A-cells, reduced B-cells and exocrine fibrosis: quantitative changes in the pancreas in Type 2 diabetes. Diabetes Res 9: 151-160

3. Schneider HM, Storkel S, Will W (1980) Das Amyloid der Langerhansschen Inseln und seine Beziehung zum Diabetes Mellitus. Dtsch Med Wochenschr 105: 1143-1147

4. Westermark P, Wilander E, Westermark GT, Johnson KH (1987) Islet amyloid polypeptide-like immunoreactivity in the islet $B$ cells of Type 2 (non-insulin-dependent) diabetic and nondiabetic individuals. Diabetologia 30: 887-892

5. Vishwanathan KA, Bazaz-Malik G, Dandekar J, Vaishnava (1972) A qualitative and quantitative histological study of the islets of Langerhans in diabetes mellitus. Indian J Med Sci 26: 807812

6. Saito K, Takahashi T, Yaginuma N, Iwama N (1978) Islet morphometry in the diabetic pancreas of man. Tohoku J Exp Med 125: 185-197

7. Bell ET (1959) Hyalinization of the islets of Langerhans in nondiabetic individuals. Am J Pathol 35: 801-805 
8. Maloy AL, Longnecker DS, Greenberg ER (1981) The relation of islet amyloid to the clinical type of diabetes. Human Pathol 12: 917-922

9. Clark A, Cooper GJS, Lewis CE, Morris JF, Willis AC, Reid KBM, Turner RC (1987) Islet amyloid formed from diabetes associated peptide may be pathogenic in type 2 diabetes. Lancet II: 231-234

10. Anonymous (1987) Pancreatic abnormalities in type 2 diabetes mellitus. Editorial, Lancet II: $1497-1498$

11. Howard CF (1986) Longitudinal studies on the development of diabetes in individual macaca nigra. Diabetologia 29:301-306

12. Westermark $P$, Wernstedt $C$, Wilander E, Hayden DW, O'Brien TD, Johnson KH (1987) Amyloid fibrils in human insulinoma and islets of Langerhans of the diabetic cat are derived from a neuropeptide-like protein also present in normal islet cells. Proc Natl Acad Sci 84: 3881-3885

13. Cooper GJS, Willis AC, Clark A, Turner RC, Sim RB, Reid KBM (1987) Purification and characterisation of a peptide from amyloid-rich pancreases of type 2 diabetic patients. Proc Nat Acad Sci 84: 8628-8632

14. Westermark P, Wernstedt C, Wilander E, Sletten K (1986) A novel peptide in the calcitonin gene-related peptide family as an amyloid fibril protein in the endocrine pancreas. Biochem Biophys Res Commun 140: 826831

15. Cooper GJS, Leighton B, Dimitriadis GD, Parry-Billings M, Kowalchuk JM, Howland K, Rothbard JB, Willis AC, Reid KBM (1988) Amylin found in amyloid deposits in human type 2 diabetes mellitus may be a hormone that regulates glycogen metabolism in skeletal muscle. Proc Natl Acad Sci 85: 7763-7766

16. Betscholz C, Christmansson L, Engstrom U, Rosman F, Svensson V, Johnson KH, Westermark P (1989) Sequence divergence in a specific region of islet amyloid polypeptide (IAPP) explains the differences in islet amyloid formation between species. FEBS Let 251: 261-264

17. Nishi M, Chan SS, Naganatsu S, Bell GI, Steiner DF (1989) Conservation of the sequence of islet amyloid polypeptide in 5 mammals is consistent with its putative role as an islet hormone. Proc Natl Acad Sci USA 86:5738-5742

18. Westermark P, Wernstedt C, O'Brien TD, Hayden DW, Johnson KH (1987) Islet amyloid in type 2 human diabetes mellitus and adult diabetic cats contains a novel putative polypeptide hormone. Am J Pathol 127: 414-417

19. Knowler WC, Bennett PH, Hamman RF, Miller M (1978) Diabetes incidence and prevalence in Pima Indians: a 19-fold greater incidence than in Rochester, Minnesota. Am J Epidemiol 108: 497-505

20. Knowler WC, Pettitt DJ, Savage PJ, Bennett PH (1981) Diabetes incidence in Pima Indians: contributions of obesity and parental diabetes. Am J Epidemiol 113: 144-156

21. Knowler WC, Pettitt DJ, Bennett PH, Williams RC (1983) Diabetes mellitus in the Pima Indians: genetic and evolutionary considerations. Am J Phys Anthrop 61: 107-114

22. Savage PJ, Dippe SE, Bennett PH et al. (1975) Hyperinsulinemia and hypoinsulinemia. Insulin response to oral carbohydrate over a wide spectrum of glucose tolerance. Diabetes 24:362-368

23. Nagulesparan M, Savage PJ, Mott DM, Johnson GC, Unger $\mathrm{RH}$, Bennett PH (1980) Increased insulin resistance in obese, glucose intolerance southwestern American Indians: evidence for a defect not explained by obesity. J Clin Endocrinol Metab 51: 739-743

24. Bogardus C, Lillioja S, Foley J, Christin L, Freymond D, Nyomba B, Bennett PH, Reaven G, Salans L (1987) Insulin resistance predicts the development of non-insulin-dependent diabetes mellitus in Pima Indians. Diabetes 36: 47 (A)

25. Lillioja S, Mott DM, Howard BV, Bennett PH, Yki-Jarvinen $\mathrm{H}$, Freymond D, Nyomba BL, Zurlo F, Swinburn B, Bogardus C (1988) Impaired glucose tolerance as a disorder of insulin action.
Longitudinal and cross-sectional studies in Pima Indians. N Engl J Med 318: 1217-1225

26. Lillioja S, Bogardus C (1988) Obesity and insulin resistance: lessons learned from the Pima Indians. Diabetes Metab Rev 4: $517-$ 540

27. Report of a WHO Study Group (1985) Diabetes mellitus. WHO Tech Rep Ser 7272: 9-17

28. Nakane PK, Pierce GB (1967) Enzyme labelled antibodies for the light and electron microscopic localisation of tissue antigens. J Cell Biol 33: 307-318

29. Savage PJ, Bennett PH, Senter RG, Miller M (1979) High prevalence of diabetes in young Pima indians. Diabetes 28: 937-942

30. Katzeff HL, Savage PJ, Barclay-White B, Nagulesparan M, Bennett PH (1985) C-peptide measurements in the differentiation of Type 1 (insulin-dependent) and Type 2 (non-insulin-dependent) diabetes mellitus. Diabetologia 17: 161-164

31. Clark A, Holman RR, Matthews DR, Hockaday TDR, Turner RC (1984) Non-uniform distribution of islet amyloid in the pancreas of 'maturity-onset' diabetic patients. Diabetologia 27: $527-528$

32. Johnson KH, O'Brien TD, Hayden DW, Ghobrial HKG, Westermark P (1988) Immunolocalization of islet amyloid polypeptide (IAPP) in pancreatic beta cells by means of peroxidase antiperoxidase (PAP) and protein $\mathrm{A}$ gold techniques. Am J Pathol 130: 1-8

33. Clark A, Edwards CA, Ostle LR, Sutton R, Rothbard JB, Morris JF, Turner RC (1988) Localisation of islet amyloid peptide in lipofuscin bodies and secretory granules of human B-cells and in islets of type-2 diabetic subjects. Cell Tiss Res 257: 179-185

34. Mosselman S, Hoppener JWM, Zandberg J, van Mansfield ADM, Geurts van Kessel AHM, Lips CJM, Jansz HS (1988) Islet amyloid polypeptide (IAPP): identification and chromosomal localization of the human gene. Febs Lett 239:227-232

35. Sanke T, Bell GI, Sample C, Rubenstein AH, Steiner DF (1988) An islet amyloid peptide is derived from an 89 amino acid precursor by proteolytic processing. J Biol Chem 263: 17243-17246

36. Westermark P, Wilander E, Johnson KH (1987) Islet amyloid polypeptide. Lancet II: 623

37. Ohsawa H, Kanatsuku A, Yamaguchi T, Makino H, Yoshida S (1989) Islet amyloid polypeptide inhibits glucose-stimulated insulin secretion from isolated rat pancreatic islets Diabetologia 32: $524 \mathrm{~A}$

38. Turner RC, Heding LG (1977) Plasma proinsulin, C-peptide and insulin in diagnostic suppression tests for insulinomas. Diabetologia 13: 571-577

39. Clark A, Matthews DR, Naylor BA, Wells CA, Hosker JP, Turner RC (1987) Pancreatic islet amyloid and elevated proinsulin secretion in familial maturity-onset diabetes. Diabetes Res 4:5155

40. O'Rahilly S, Turner RC, Matthews DR (1988) Impaired pulsatile secretion of insulin in relatives of patients with non-insulindependent diabetes. N Engl J Med 318: 1225-1230

41. Turner RC, Rudenski AS, Holman RR, Matthews DR, O'Rahilly SP (1987) Quantitative modelling of endocrine diseases. Clin Endocrinol 26: 107-116

Received: 26 June 1989

and in revised form: 27 November 1989

Dr. A. Clark

Diabetes Research Laboratories

Radcliffe Infirmary

Woodstock Road

Oxford OX2 6HE

UK 